\title{
Enterprise Arsitektur Planning (EAP) untuk Universitas Pattimura Menggunakan TOGAF ADM
}

\author{
Roberth E. Pariama ${ }^{1}$, Andi W. R. Emanuel ${ }^{2}$ \\ Universitas Atma Jaya Yogyakarta; Kampus III Gedung Boneventura, Jln. Babarsari 43 \\ Yogyakarta, telp: 0274-487711 / fax: 0274-485223 \\ Magister Informatika, Universitas Atma Jaya Yogyakarta \\ e-mail: ${ }^{1}$ roberth.everthardus@ti.ukdw.ac.id, ${ }^{2}$ andi.emanuel@uajy.ac.id
}

\begin{abstract}
Abstrak
Penerapan Enterprise Arsitektur (EA) merupakan konsep yang dibutuhkan oleh perguruan tinggi. Penerapan EA bertujuan membantu menyelesaikan dinamika yang ada. Universitas Pattimura belum menerapkannya dan hampir semua konsep penerapan masih belum teroganisir dengan baik salah satu contoh yang belum dilakukan adalah layanan data, aplikasi dan teknologi masih manual. Rencana Strategi dan Rencana Induk Pengembangan Universitas Pattimura menjadi acuan penerapan EAP, wawancara kepada mahasiswa, Dosen dan Karyawan bagian pengelolaan TI menjadi metode penelitian penulis, sehingga menemukan data kongkrit untuk dapat merencanakan EA Universitas Pattimura. TOGAF ADM merupakan sebuah kerangka kerja atau framework yang mampu mengatur sebuah arsitektur perusahan, dan juga merupakan sebuah metode mengembangkan arsitektur sebuah korporat yang dipakai oleh peneliti. Blueprint arsitektur bisnis, data, aplikasi sistem informasi dan teknologi merupakan hasil dari pemodelan EA yang diterapkan pada ruang lingkup Universitas Pattimura. TOGAF ADM pada fase Preliminary Phase atau fase awal mengidentifikasi suatu korporat dari arsitektur bisnis, data, aplikasi dan teknologi. Pada fase Vision Architecture menghasilkan visi arsitektur yaitu arsitektur bisnis, data, aplikasi dan teknologi. Pada fase Business Architecture menghasilkan blueprint arsitektur bisnis. Pada fase Information System Architecture menghasilkan blueprint arsitektur SI, dan pada fase Technology Architecture menghasilkan blueprint arsitektur TI. Penerapan EAP pada Universitas Pattimura membawa dampak positif karena menghasilkan keselarasan strategi bisnis dan strategi TI sehingga penting untuk diterapkan.
\end{abstract}

Kata kunci-Enterprise Architecture, TI/SI, TOGAF ADM

\begin{abstract}
Application of Enterprise Architecture (EA) is a concept needed by universities. Application of EA that helps resolve existing dynamics. Pattimura University has not implemented it and almost all of the concepts of application are still not organized with one example that has not been done is that data services, applications, and technology are still manual. The Strategic Plan and Master Plan for Pattimura University Development become a reference for the implementation of EAP, interviews for students, lecturers and employees in the IT management section are the author's research methods, so that finding concrete data can be used by Pattimura University EA. TOGAF ADM is a framework that enables company architecture, and also a method that develops the architecture of a company that is used by researchers. Blueprints of business architecture, data, information systems and technology applications are the results of EA modeling that is applied to the Pattimura University distribution room. TOGAF ADM in the Early Phase or early phase of a corporation, data, application, and technology. In the Architecture Vision phase, it produces an architectural vision of business, data, application and technology architecture. In the Business Architecture phase, it produces a business architecture blueprint. In the Information Systems Architecture
\end{abstract}


phase, it produces a blueprint for SI architecture, and in the Technology Architecture phase, it produces a blueprint for IT architecture. The implementation of EAP at Pattimura University has a positive impact because it results in the alignment of business strategies and IT strategies that are very important to implement.

Keywords - Enterprise Architecture, TI/SI, TOGAF ADM

\section{PENDAHULUAN}

Enterprise Architecture (EA) merupakan pemetaan sebuah organisasi untuk menyelelaraskan strategi bisnis dengan strategi TI yang bertujuan untuk mengintegrasikan sebuah SI perusahan atau korporat meliputi proses, unit organisasi maupun stakeholder yang berada di dalamnya [1]. Universitas Pattimura merupakan sebuah perguruan tinggi yang perlu mengimplementasikan EA dalam semua aspek agar secara strategis menciptakan sebuah sistem yang terintegrasi. EA berperan sangat besar untuk sebuah organisasi yang mana EA sudah dibentuk sejak 30 tahun lalu dan tidak diragukan lagi untuk penerapannya [2]. Namun ada beberapa perusahan masih menghadapi masalah terkait proses implementasi EA karena proses implementasi EA bukanlah salah satu proses yang mudah, untuk itu Universitas Pattimura memerlukan implementasi EA untuk menyelaraskan kebutuhan bisnis dan kebutuhan TI dan SI managemen agar semua unit kerja saling terintegrasi. Menurut beberapa penelitian di Belanda lebih dari $66 \%$ implementasi EA tidak sesuai harapan, penggunaan EA framework di Amerika Serikat juga menghasilkan hal yang sama selain itu salah satu negara di Asia Tenggara, Malaysia implementasi EA juga belum mengalami kesuksesan pada sektor publik [1] [3]. Namun penggunaan EA dapat menghasilkan nilai positif bagi sebuah korporasi atau perusahan [4]. Untuk dapat mencapai nilai ini sangat terbukti lebih rumit [5]

Keselarasan strategi bisnis dan TI merupakan proses yang selaras dan berkelanjutan, mengapa demikian karena selalu dipengaruhi oleh perubahan dan perkembangan pasar selain itu berpengaruh dari perkembangan TI saat ini yang semakin pesat maka mempengaruhi strategi bisnis dari suatu organisasi [6]. Tujuannya yaitu dapat meningkatkan SI pada lingkungan Universitas dan memberikan layanan yang baik kepada mahasiswa, stakeholder maupun Dosen dengan strategi bisnis [1]. Meskipun EA sudah muncul 30 tahun yang lalu namun masih saja menghadapi banyak tantangan kredibilitas, dikarenakan para pakar AE tidak melihat nilai yang dikembalikan dari inverstasi yang dilakukan [7]. Untuk itu perlu penerapan AE yang komprehensif untuk kepentingan sebuah Universitas skala besar.

Penelitian ini bertujuan untuk mendapatkan pemahaman yang baik dan menyeluruh tentang keuntungan fungsi dan peran dari EA yang diimplementasikan pada Universitas Pattimura. Hasil dari penelitian ini memaparkan blueprint dari masing-masing aspek, mulai dari blueprint strategi bisnis maupun strategi TI, SI dalam bentuk data dan aplikasi. Penelitian ini diakhiri dengan rekomendasi untuk penelitian dan penerapan lanjutan EA pada Universitas Pattimura agar segera diterapkan dan mendatangkan nilai positif dari EA untuk kepentingan seluruh civitas akademik.

\section{METODE PENELITIAN}

Metode yang dilakukan untuk proses penelitian ini yaitu studi lapangan dan dilakukan tinjauan secara komprehensif memahami dan mendalami rencana strategi, rencana induk pengembangan, studi literatur, form kuisioner dan hasil wawancara dari Universitas Pattimura untuk mendapatkan data yang diinginkan. Peneliti melakukan pengamatan proses bisnis

Pariama, et., al (Enterprise Arsitektur Planning (EAP) untuk Universitas Pattimura Menggunakan TOGAF ADM) 
Universitas Pattimura saat ini dengan strategi TI wawacara dengan mahasiswa, dosen dan Bagian pengelolaan TI. Setelah mendapatkan data-data yang diperlukan maka disimpulkan dan selanjutnya dilakukan Enterprise Architecture Planning (EAP) menggunakan TOGAF ADM dengan 5 Tahap yaitu Tahap awal (Preliminary), Visi Arsitektur, Arsitektur Bisnis, Arsitektur Sistem Informasi, dan Arsitektur teknologi untuk menjadi acuan penerapan EA pada Universitas Pattimura. Hasil akhir dari penelitian ini yaitu memaparkan blueprint dari EAP meliputi blueprint bisnis, data, aplikasi sistem informasi dan teknologi informasi.

\section{LANDASAN TEORI}

\subsection{Enterprise Architecture (EA)}

EA merupakan salah satu metode yang dapat mengoptimalkan strategi bisnis, strategi IT yang dapat diimplementasikan pada sebuah korporat atau organisasi yang dibuat dan didukung oleh beberapa kerangka pengembangan misalnya TOGAF ADM, Cobit, ITIL dll [8] [9]. EA menghasilkan blueprint yang menjadi acuan penerapannya mengomptimalkan sumber daya dilingkungan TI dan selalu mendukung fungsi-fungsi bisnis agar selaras [10]. Ada banyak pandangan maupun definisi dan nilai EA tergantung dari aspek korporat dan bisnis maupun TI yang sedang berkembang [11]. Contohnya klasifikasi nilai EA dalam suatu organisasi yang mana melihat dari gambaran sebuah proyek [5].

AE juga merupakan himpunan representasi deskriptif yang tentu sangat diperlukan dalam mengelola suatu objek dari perusahan. Jika menemukan sebuah objek maka dapat dengan mudah melihat arsitekturnya [3]. Selain itu EA dapat diartikan bahwa keseluruhan prinsip yang serasi atau kompak mulai dari metodenya yang digunakan dalam suatu korporat dengan proses bisnis, infrastruktur maupun semua SI yang ada. [12]. Dalam penerapannya EA tergantung satu sama lain berdasarkan komponennya, hubungan satu sama lain dengan kondisi lingkungan atau kondisi bisnis yang ada dan mengatur prinsip-prinsip desain dan perubahannya [9].

\subsection{TOGAF ADM}

TOGAF (The Open Group Architecture Framework) adalah salah satu kerangka kerja atau framework yang mampu mengatur sebuah arsitektur perusahan, sebuah metode mengembangkan arsitektur sebuah korporat [14] [10].

TOGAF merancang model proses yang disebut Architecture Development Method (ADM). Yang terdiri dari beberapa Tahap yang memiliki tujuan masing-masing, pendekatan, langkah, input maupun outputnya sesuai Tahap yang ada [15]. Pada setiap Tahap kemungkinan tidak menghasilkan hasil yang baik karena kurangnya pemantaun dari sebuah perusahan [16]. Berikut contoh ADM dari TOGAF.

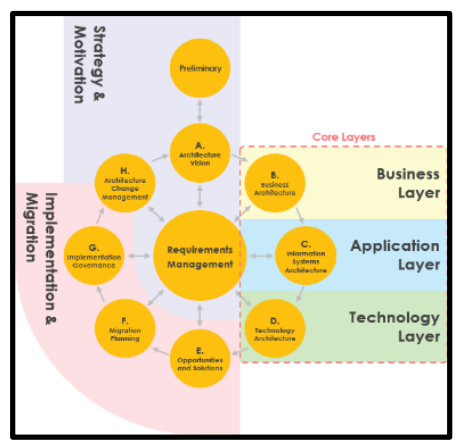

Gambar 1. TOGAF ADM (Architecture Development Method) 
Ada 3 domain dasar arsitekturnya yaitu Arsitektur Bisnis, Arsitektur Sistem Informasi dan Arsitektur Teknologi [10] [15]. Berdasarkan 3 domain dasar pemodelan arsitektur TOGAF ADM tersebut, maka 5 langkah ini yang diterapkan antara lain [15] [8]:

1. Tahap Preliminary

Proses persiapan organisasi untuk bagaimana menerapkan pengembangan arsitektur TOGAF ADM. Dengan cara melakukan inisiasi yang dianggap penting untuk membuat kemampuan arsitekturnya.

2. Tahap A: Architecture Vision

Pada Tahap ini menerapkan kendala dan harapan untuk dapat menerapkan pengembangan arsitektur menggunakan TOGAF ADM pada ruang lingkup suatu korporat.

3. Tahap B: Business Architecture

Pada Tahap ini menerapkan proses secara detail dari Tahap sebelumnya. Pada Tahap ini dilakukan identifikasi awal arsitektur bisnis dan menentukan business art enterprise (Seni dalam berbisnis), dimana visi arsitektur dan seni berbisnis dianalisa kesenjangannya.

4. Tahap C: Information Systems Architecture

Pada Tahap ini dilakukan pembangunan aplikasi arsitektur dan data arsitektur untuk saling menunjang kebutuhan dari proses bisnis enterprise tersebut.

5. Tahap D: Technology Architecture

Pada Tahap ini diusulkan arsitektur yang dapat saling terhubung. Meliputi persiapan Perangkat keras atau hardware dan jaringan komputer yang saling mendukung untuk dapat menerapkan arsitektur sistem informasi.

\section{HASIL DAN PEMBAHASAN}

Peneliti menggunakan kerangka kerja TOGAF ADM untuk merancang EA Universitas Pattimura yang mendukung semua proses akademik dan non akademik meliputi Sistem informasi (SI) dan Teknologi informasi (TI). Tahapan-tahapan TOGAF ADM menjadi acuan merancang EA mulai dari tahapan awal yaitu Preliminary Phase, Visi Arsitektur (Vision Architecture), Bisnis Arsitektur (Business Architecture), Sistem Informasi (Information System Architecture), dan Teknologi Arsitektur (Technology Architecture).

\subsection{Fase Preliminary}

Pada bagian ini peneliti melakukan identifikasi tahap awal melalui proses kuisioner dengan 43 mahasiswa dan 5 pegawai bagian pengelolaan teknologi informasi, 5 dosen dan 10 Almuni untuk dapat mengetahui kondisi awal EA yang digunakan oleh UNPATTI. Peneliti menemukan beberapa kekurangan dalam implementasi IT. Universitas Pattimura yang disingkat UNPATTI dengan moto Hotumese (Berkembang dalam Tantangan) ini merupakan perguruan tinggi negeri yang bertempat di Ambon, Maluku yang berdiri sejak tahun 8 Agustus 1963. Namun, sejak awal pendirian UNPATTI masih kurang merencanangkan Enterprise Arsitekturnya sehingga belum maksimal model bisnisnya dan pengembangan SI atau TI. Berikut penjelasannya

A. Sistem Aplikasi yang belum terintegrasi.

Secara umum Universitas Pattimura hanya memiliki sistem informasi sederhana.

- Beberapa aktivitas akademik pengeloaan data-data akademik maupun non akademik masih manual menggunakan MS Office.

- Sistem registrasi online yang dulu ada, namun tidak dijalankan lagi karena kurang ada pemeliharaan sistem. 
- Tidak menggunakan platform, yang mana platform ini mempermudah mahasiswa dapat menikmati produk-produk original dari platform yang dipakai. Contohnya Windows, Microsoft, Oracle, SAP dll

- Penggunaan aplikasi software yang tidak berlisensi (Contohnya MS Office, Office 365)

- Sistem informasi mahasiswa belum dibentuk, sehingga untuk dapat melihat nilai dan kartu rencana studi harus membuang waktu ke kampus.

- Selain itu web perpustakaan belum dibentuk sehingga secara umum disimpulkan managemen sistem informasi yang terintegrasi belum dikatakan baik dan perlu penerapan EA untuk penyempurnaan.

- Email Student belum diterapkan oleh universitas.

- Sistem Informasi Tugas akhir juga belum dibentuk oleh UNPATTI

- Sidik jari untuk proses absensi mahasiswa dan dosen belum diterapkan

B. Penggunaan Infrastruktur Jaringan Komputer

- Tidak membangun infrastruktur atau topologi jaringan komputer secara mandiri.

- Keamanan jaringan komputer yang masih kurang untuk terhindar dari serangan virus, trojan maupun malware dll.

- Fasilitas wifi masih terbatas, tidak semua tempat dapat menggunakan wi-fi kampus.

- Tidak ada hardware jaringan yang mampu mengatur proses-proses jaringan komputer.

- Pemeliharaan jaringan komputer secara menyeluruh belum ada.

- Fasilitas wifi area kampus belum maksimal.

- Tidak membangun administrasi jaringan yang fungsinya menginstal dan mengkonfirmasi server, mengelola user, backup atau restore file, mengkonfirmasi keamanan jaringan dll.

- Tidak ada tool yang memonitoring keamanan jaringan dll

Pada prinsipnya peneliti menemukan bahwa UNPATTI masih membutuhkan prinsip arsitektur yang baik misalnya prinsip arsitektur bisnis, aplikasi, teknologi dan data. Padahal pentingnya membangun prinsip arsitektur merupakan hal yang positif yaitu dapat digunakan untuk pengembangan EA. Untuk itu Universitas Pattimura dengan ini dapat dibantu dalam penerapan prinsip arsitektur oleh TOGAF ADM framework. Dari hasil diskusi dengan bidang pengelolaan TI maka dapat dibentuk prinsip-prinsip arsitektur yang diterapkan oleh TOGAF ADM framework dengan Universitas Pattimura menemukan perjanjian perencanaan pembangunan arsitektur bisnis dan TI sebagai berikut.

Tabel 1. Hasil Tahapan Awal

\begin{tabular}{|c|c|l|}
\hline \multirow{2}{*}{ No } & \multicolumn{2}{|c|}{ Hasil } \\
\hline \multirow{4}{*}{1} & \multirow{4}{*}{ Prinsip Bisnis } & Optimis dalam pembangunan bisnis Universitas Pattimura \\
\cline { 3 - 3 } & & Ambisi dan sabar dalam pembangunan bisnis \\
\cline { 3 - 3 } & & Mampu melihat peluang berbisnis (Pasar) \\
\cline { 3 - 3 } 2 & \multirow{4}{*}{ Pridak putus asa (Semangat) dalam membangun bisnis } \\
\cline { 3 - 3 } & & Proses bisnis yang Inovatif dan kreatif \\
\cline { 3 - 3 } & & Proses bisnis yang mandri \\
\hline & & $\begin{array}{l}\text { Data merupakan aset yang dapat di kelola dengan baik dan } \\
\text { terintegrasi }\end{array}$ \\
\cline { 3 - 3 } & & Akses level dalam mengelola data \\
\cline { 3 - 3 } & & Penyimpanan data yang memenuhi kapasitas \\
\hline
\end{tabular}

Pariama, et., al (Enterprise Arsitektur Planning (EAP) untuk Universitas Pattimura Menggunakan TOGAF ADM) 


\begin{tabular}{|c|c|c|}
\hline & & Klasifikasi data sesuai kategori \\
\hline & & Up to date dalam pengelolaan data \\
\hline & & Pemeriksaan data secara berkala, kalkulasi data numerik. \\
\hline & & Sorting data atau filterisasi data sesuai bidang/unit pengelola dll \\
\hline \multirow{4}{*}{3} & \multirow{4}{*}{ Prinsip Aplikasi } & Aplikasi yang terintegrasi \\
\hline & & Menjamin keamanan aplikasi \\
\hline & & Akses level aplikasi sesuai jabatan stakeholder \\
\hline & & $\begin{array}{l}\text { Menggunakan Enterprise Resource Planning (Aplikasi yang } \\
\text { terintegrasi yang mencakup multi fungsional) }\end{array}$ \\
\hline \multirow{5}{*}{4} & \multirow{5}{*}{$\begin{array}{l}\text { Prinsip } \\
\text { Teknologi } \\
\text { Informasi }\end{array}$} & Kemandirian teknologi \\
\hline & & Teknologi yang up to date \\
\hline & & Perangkat keras yang memadai \\
\hline & & Keamanan jaringan sesuai standart \\
\hline & & Mindmaping prinsip teknologi \\
\hline
\end{tabular}

\subsection{Fase: Architecture Vision}

Visi arsitektur mengidentifikasi ruang lingkup, kendala, dan harapan atau visi untuk dapat menerapkan pengembangan EA menggunakan TOGAF ADM pada Universitas Pattimura agar para stakeholder memiliki perhatian ekstra untuk proses-proses implementasinya. Berikut analisis visi arsitektur Universitas Pattimura.

\subsubsection{Analisis Proses Bisnis.}

Kesimpulan dari data yang didapat maka peneliti menganalisis proses bisnis yang kini diterapkan oleh Universitas Pattimura.

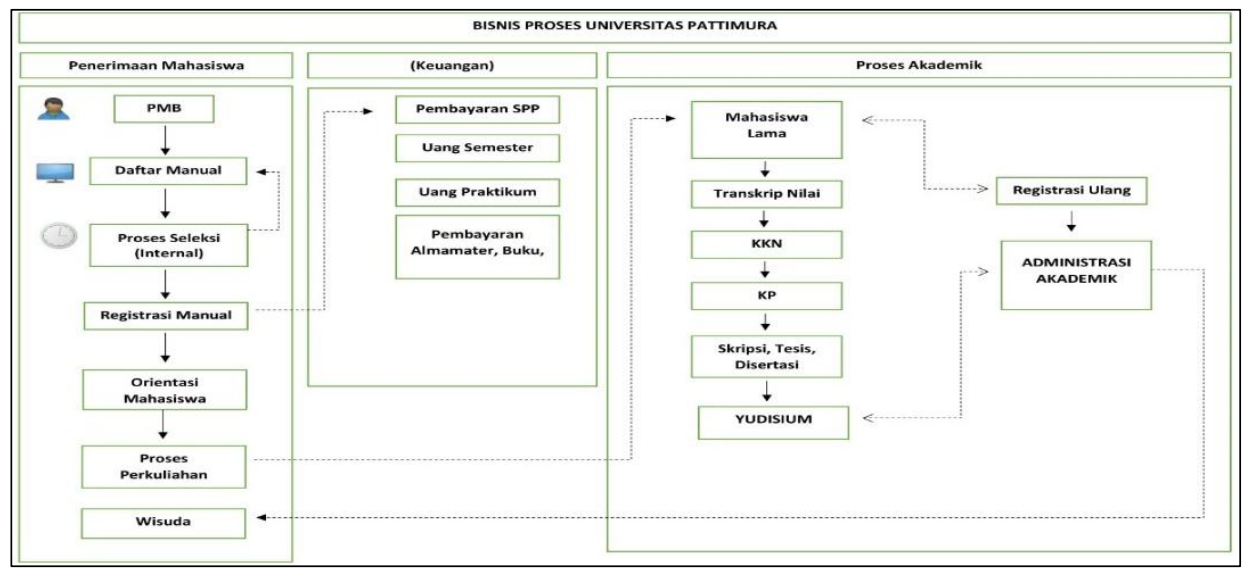

Gambar 2. Value Chain Proses Bisnis

\subsubsection{Identifikasi Sumber Daya Manusia (Stakeholder).}

Dari hasil penelitian di lapangan Karyawan yang mengelola tidak semua memiliki latar belakang IT sehingga untuk proses - proses pemeliharaan layanan IT mengalami kesulitan, sehingga dibutuhkan tenaga dari luar untuk proses-proses pemeliharaan sistem yang ada. Untuk itu dengan adanya perencanaan arsitektur enterprise ini dapat membantu dan memahami secara komprehensif prinsip-prinsip kerja dari EA untuk dapat diterapkan menjadi bahan penyempurnaan pada Universitas Pattimura. 


\subsubsection{Analisis Lingkungan.}

1. Internal

Tahap ini lebih mengkaji pada kondisi internal dari Universitas Pattimura. Dalam moto UNPATTI yaitu Hotumese (Berkembang dalam tantangan) artinya bagaimana institusi ini mampu menghadapi tantangan demi tantangan revolusi industri 4.0 dalam memajukan UNPATTI ke depan. Dapat diuraikan bahwa UNPATTI berfokus pada peningkatan kualitas sumber daya manusia, mengembangkan Ilmu pengetahuan dan teknologi seni, kajian dan penelitian bagi kepentingan pembangunan masyarakat dan melaksanakan Tri-Dharma perguruan tinggi sesuai standar Nasional Pendidikan Tinggi.

Berikut analisis lingkungan internal

a. Pola Ilmiah Pokok UNPATTI yang menegaskan bahwa laut Maluku yang kaya perlu secara arif, efisien dan lestasri untuk di kelola.

b. Bidang unggulan memiliki 9 fakultas, 67 program studi untuk pengembangan bidang unggulan.

c. Sistem tata kelola organisasi managemen dan pengelolaan keuangan.

d. Sistem penjaminan mutu.

e. Sumber daya manusia meliputi Dosen, karyawan dan mahasiswa.

f. Sarana prasarana yang salah satunya meningkatkan teknologi informasi.

2. External

Tahapan ini peneliti melihat faktor external apa saja yang mempengaruhi proses bisnis Universitas Pattimura antara lain:

a. Posisi strategis Maluku

b. Sumber daya alam

c. Kebijakan pemerintahan

d. Otonomi Daerah

Dari hasil penelitian di atas tentang Visi arsitektur Universitas Pattimura mengenai proses bisnis, pengaruh lingkungan internal dan external maka dapat disimpulkan secara keseluruhan visi arsitektur dan menjadi bahan penyempurnaan antara lain.

Tabel 2. Hasil Analisis Visi Arsitektur

\begin{tabular}{|c|l|l|}
\hline No & \multicolumn{2}{|c|}{ Proses } \\
\hline 1 & $\begin{array}{l}\text { Visi } \\
\text { Arsitektur } \\
\text { Bisnis }\end{array}$ & $\begin{array}{l}\text { Menjamin efisiensi dan keefektifan dalam menata kelola sistem informasi } \\
\text { yang terintegrasi untuk semua stakeholder agar dapat berkomunikasi, } \\
\text { berkolaborasi dan berbagi. }\end{array}$ \\
\hline 2 & $\begin{array}{l}\text { Visi } \\
\text { Arsitektur } \\
\text { Data }\end{array}$ & $\begin{array}{l}\text { Mengelola data yang terbaik dari hasil filterisasi dan sorting data untuk } \\
\text { dapat dipraktekan dalam manajemen informasi, data dan aset penting } \\
\text { Universitas Pattimura }\end{array}$ \\
\hline 3 & $\begin{array}{l}\text { Visi } \\
\text { Arsitektur } \\
\text { Aplikasi }\end{array}$ & $\begin{array}{l}\text { Menjamin kerjasama dengan platform aplikasi software dan hardware } \\
\text { dalam meningkatkan konsep ERP (Enterprise Resource Planning) untuk } \\
\text { menciptakan layanan TI bagi mahasiswa dan pemangku kepentingan. } \\
\text { Misalnya pendaftaran mahasiswa baru menggunakan sistem, pengelolaan } \\
\text { data dll. }\end{array}$ \\
\hline 4 & $\begin{array}{l}\text { Visi } \\
\text { Arsitektur } \\
\text { Teknologi }\end{array}$ & $\begin{array}{l}\text { Universitas, pengembangan teknologi, managemen bisnis, proses } \\
\text { akademik dan non akademik yang terintegrasi serta pendekatan hemat } \\
\text { biaya. }\end{array}$ \\
\hline
\end{tabular}

Pariama, et., al (Enterprise Arsitektur Planning (EAP) untuk Universitas Pattimura Menggunakan TOGAF ADM) 


\subsection{Fase: Business Architecture}

Pada fase ini, peneliti mengidentifikasi arsitektur bisnis yang selama ini diterapkan oleh UNPATTI meliputi layanan dan proses bisnis. Setiap bidang organisasi terdapat perbedaan proses bisnis dan layanan bisnis, dilihat dari proses yang dilakukan ada penggunaan layanan secara manual dan ada juga dengan layanan elektronik. Cara yang digunakan untuk mendapatkan informasi arsitektur bisnis dilakukan indentifikasi kondisi awal dan target yang ada, kemudian lakukan analisis kesenjangan.

\subsubsection{Identifikasi Layanan dan Proses Bisnis}

Berdasarkan struktur organisasi UNPATTI maka dapat dilihat proses bisnisnya. Unit-unit organisasi memiliki 4 kelompok yaitu

a. Bagian eksekutif (Rektor dan Wakil rektor)

b. Kantor penjaminan mutu (KPM) terdiri dari Sistem informasi manajemen penjaminan mutu, unit latihan dan kerja sama (LKS) dan Audit mutu intenal (AMI)

c. Fakultas, jurusan dan prodi

d. Komisi koordinasi kegiatan sistem penjaminan mutu internal (SPMI), tim koordinasi kegiatan akademik dan tim kordinasi semester

\subsubsection{Proses Bisnis Dasar dan Target}

Pada fase ini melihat proses bisnis awal dari UNPATTI dan selanjutnya bersama dibuat target untuk arsitektur bisnisnya.

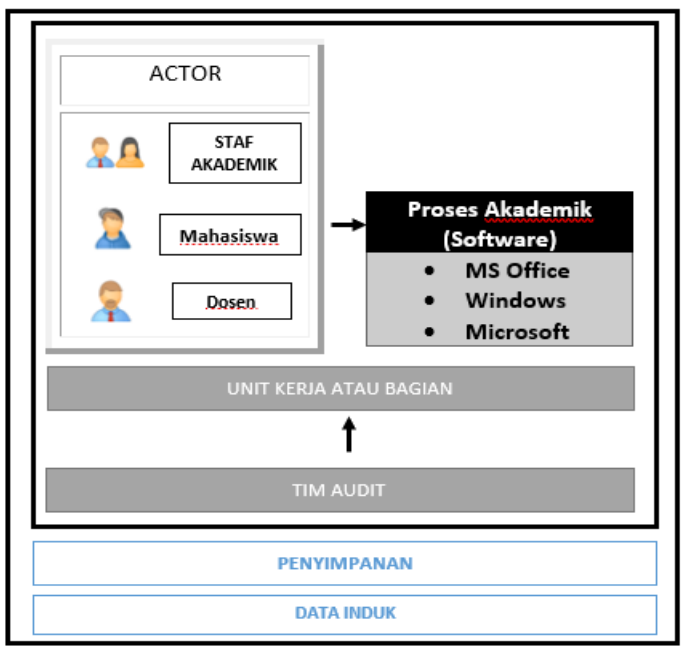

Gambar 3. Arsitektur Bisnis Awal

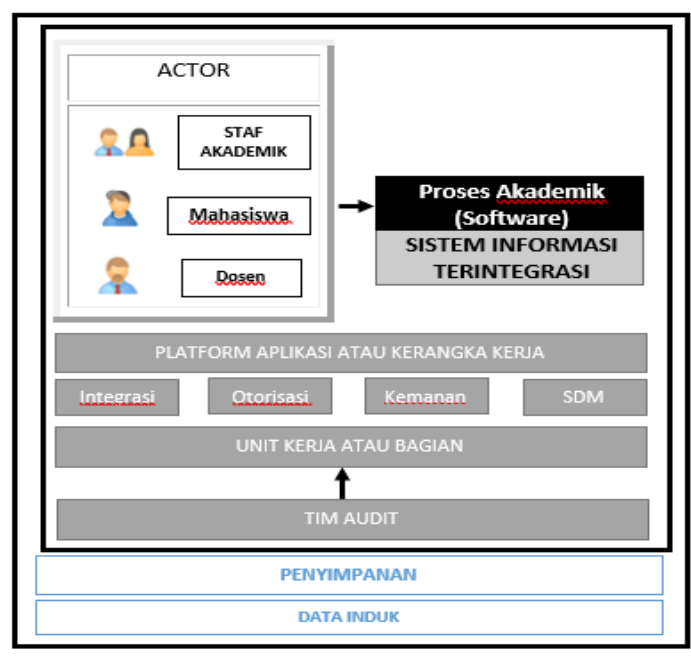

Gambar 4. Arsitektur Bisnis Target

\subsubsection{Analisis Kenjangan Bisnis Arsitektur}

Tabel 3. Target Proses Bisnis UNPATTI

\begin{tabular}{|c|l|l|}
\hline No & \multicolumn{1}{|c|}{$\begin{array}{c}\text { Informasi Dasar } \\
\text { (Bisnis Arsitektur) }\end{array}$} & \multicolumn{1}{c|}{ Target } \\
\hline 1 & $\begin{array}{l}\text { 20\% seluruh proses akademik } \\
\text { masih manual }\end{array}$ & $\begin{array}{l}\text { 100\% seluruh proses akademik } \\
\text { terkomputerisasi dan menggunakan sistem } \\
\text { informasi yang integrasi }\end{array}$ \\
\hline $\begin{array}{l}\text { Saran: } \\
\text { a) Disarankan menggunakan konsep aplikasi enterprise resource planing (ERP) yang mana } \\
\\
\text { ERP dapat meningkatkan efisien dalam operasi bisnis dan efektivitas pengambilan }\end{array}$ \\
\hline
\end{tabular}

Pariama, et., al (Enterprise Arsitektur Planning (EAP) untuk Universitas Pattimura Menggunakan TOGAF ADM) 
keputusan. ERP sangat berperan dalam proses akademis, dimana mampu menciptakan persaingan dalam berbisnis.

b) Disarankan menggunakan konsep topologi jaringan yang baik, dengan mempertimbangkan tingkat keamanan dan stabilitas suatu produk jaringan agar semua dapat terhubung secara baik dalam menjalankan aplikasi SI yang dibuat.

c) Bekerjasama dengan Platform Aplikasi untuk mendapat lisensi untuk proses akademik.

1 Tidak memiliki EA $(0 \%)$ $100 \%$ Perancangan EA untuk semua unit kerja. Saran:

a) Mulai membentuk dan memilih EA untuk meningkatkan semua proses akademik

b) Sarana prasarana yang menunjang peningkatan EA (alat, bahan, biaya)

c) Rekrutmen untuk IT support.

1. Tidak menggunakan Sistem

Keamanan jaringan (Penanganan)

Menggunakan firewall, proxi maupun kemanan lainnya untuk mejamin keamanan data dan informasi

Saran:

a) Otorisasi akses perlu digunakan (Password atau Kata Sandi, Sidik jari)

b) Pemeliharaan Perangkat keras jaringan dengan baik, agar operasi jaringan tetap prima.

c) Anti-virus up-to date (Dipasang pada semua perangkat komputer dan jaringan)

d) Menyimpan data-data penting, informasi di cloud agar terhindar kerusakan data yang terjadi akibat bencana (Penanganan bencana)

\begin{tabular}{c|l|l|}
2 & $\begin{array}{l}30 \% \text { Sumber daya manusia pada } \\
\text { bidang TI. }\end{array}$ & $\begin{array}{l}100 \% \text { Sumber daya manusia yang handal, yang } \\
\text { mampu menyelesaikan masalah-masalah IT. }\end{array}$ \\
\hline
\end{tabular}
Saran:

a) Perlu rekrutmen SDM yang handal.

b) Jaminan kesejahtraan untuk tenaga IT.

\subsubsection{Fase: Information Systems Architecture}

Pada fase ini, peneliti melakukan analisis arsitektur SI UNPATTI dan melakukan pemetaan antara informasi dasar yang didapatkan dan mengembangkan arsitektur SI sesuai target yang diinginkan.

Tabel 4. Hasil Analisis Arsitektur SI

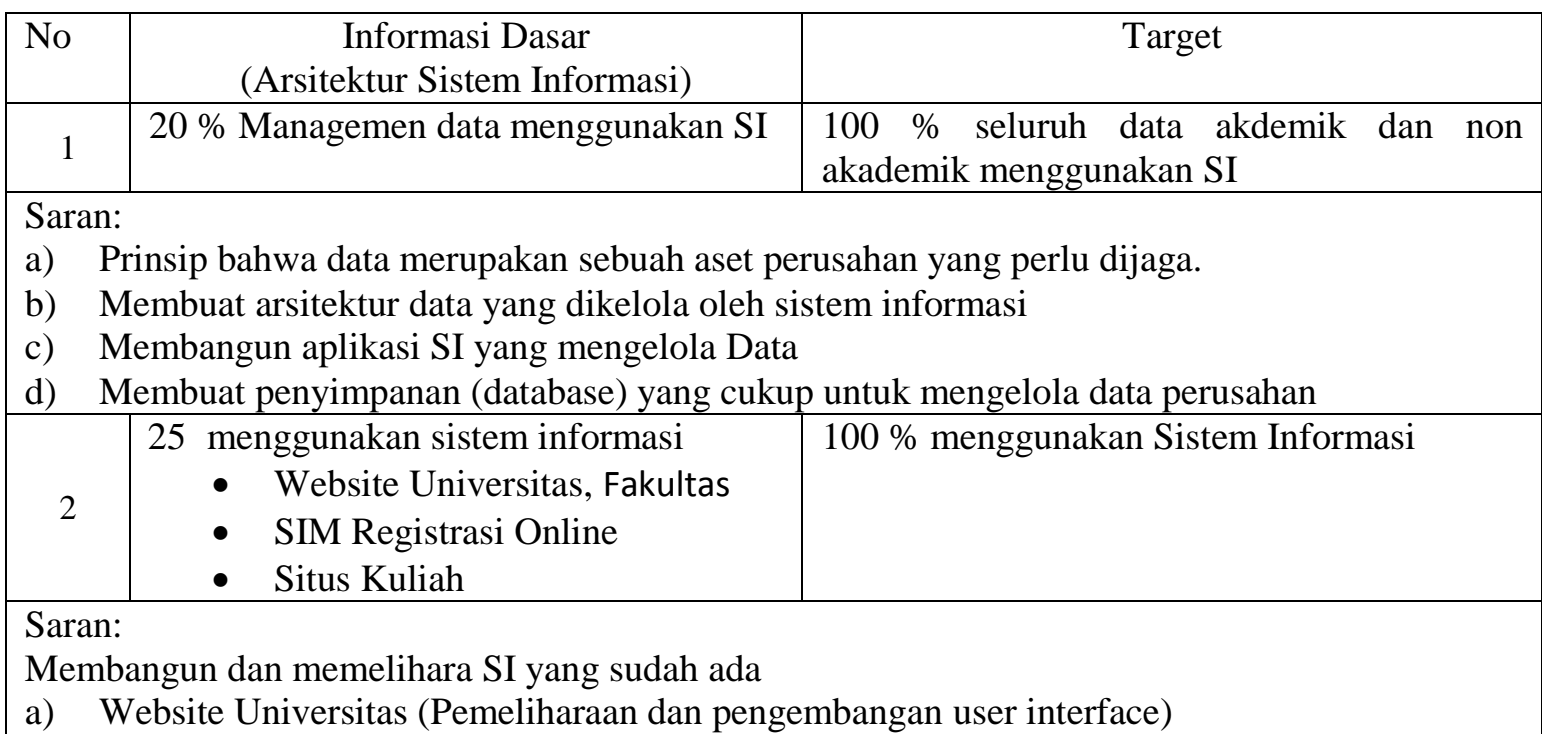

Pariama, et., al (Enterprise Arsitektur Planning (EAP) untuk Universitas Pattimura Menggunakan TOGAF ADM) 


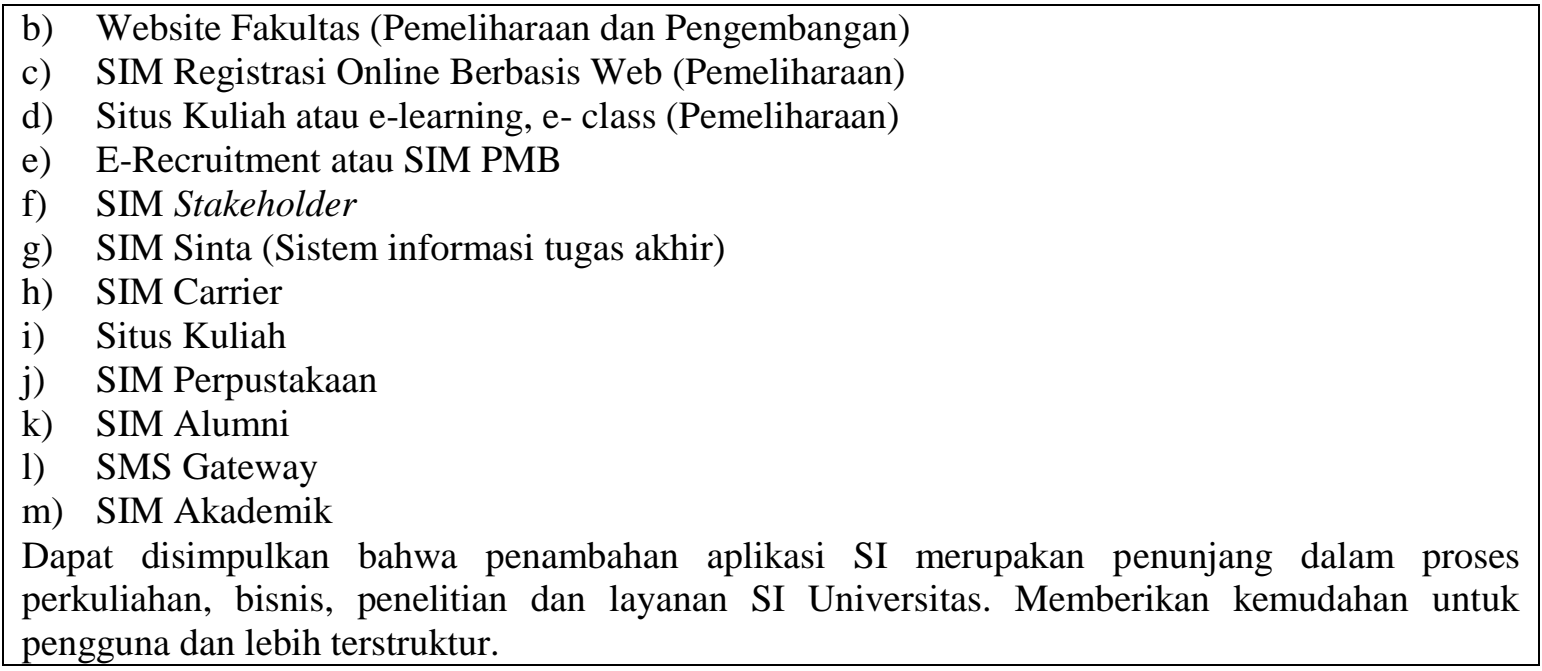

\subsubsection{Fase: Technology Architecture}

Pada fase ini, peneliti menganalisis arsitektur teknologi yang ada, kemudian melakukan perubahan arsitektur teknologi sesuai target yang diinginkan.

Tabel 5. Hasil Analisis Arsitektur TI

\begin{tabular}{|c|c|c|}
\hline No & & Target \\
\hline 1. & $\begin{array}{l}20 \% \text { Aktivitas akademik dan non } \\
\text { akademik terkomputerisasi } \\
\text { - Pengelolaan data beasiswa } \\
\text { - Pengelolaan data Perpustakaan }\end{array}$ & $100 \%$ seluruh aktivitas terkomputerisasi \\
\hline \multicolumn{3}{|c|}{$\begin{aligned} & \text { Saran: } \\
& \text { a. } \text { Mulai dibangun sistem yang mengelola parkiran. } \\
& \text { b. Monitoring menggunakan CCTV pada semua gedung. } \\
& \text { c. Absensi menggunakan sidik jari untuk semua Dosen, mahasiswa maupun karyawan } \\
& \text { d. Spesifikasi perangkat keras sering diupdate }\end{aligned}$} \\
\hline 2. & $\begin{array}{l}15 \% \text { Menggunakan topologi jaringan } \\
\text { - Rektorat } \\
\text { - Perpustakaan } \\
\text { - Lab komputer }\end{array}$ & $\begin{array}{l}100 \% \text { kepentingan konektifitas semua unit } \\
\text { menggunakan topologi jaringan }\end{array}$ \\
\hline \multicolumn{3}{|c|}{$\begin{array}{l}\text { Saran: } \\
\text { a. Mulai dibangun Teknologi VLAN (untuk kepentingan unit kerja) } \\
\text { b. Maintenance jaringan secara berkala. } \\
\text { c. Area hotspot pada semua gedung Universitas Pattimura. } \\
\text { d. Mulai dibangun ruang Server yang aman. } \\
\text { e. Penggunaan UPS untuk semua perangkat keras jaringan dan komputer } \\
\text { f. Implementasi Prinsip kerja UTM (Unified Threat Manajemen), untuk memantau kinerja } \\
\text { jaringan meliputi keamanan jaringan (Antivirus, proxi maupun gateway) } \\
\text { g. Perlu ada kerjasama dengan platform penyedia layanan jaringan (Cisco, mikrotik dll) } \\
\text { h. Menggunakan kabel UTP standar dan resmi (UTP CAT 6) } \\
\text { i. Kapasitas RAM yang cukup pada server. } \\
\text { j. Pengadaan Access Point. } \\
\text { k. Pemasangan line telepon untuk unit kerja saling berkomunikasi (ruang kelas) }\end{array}$} \\
\hline
\end{tabular}


1. Membentuk keamanan jaringan

Selanjutnya dari hasil diatas maka saran untuk membangun arsitektur enterprise UNPATTI berdasarkan waktu yaitu jangka pendek, menengah maupun rencana jangka panjang untuk mendukung proses akamedik dan non akademik UNPATTI EA.

Tabel 6. Rencana EAP UNPATTI

\begin{tabular}{|c|c|c|}
\hline $\begin{array}{c}\text { Rencana Jangka Pendek } \\
\text { (1 tahun kedepan) } \\
2020\end{array}$ & $\begin{array}{c}\text { Rencana Menengah } \\
(2-5 \text { tahun kedepan }) \\
\text { 2025 }\end{array}$ & $\begin{array}{c}\text { Rencana Jangka Panjang } \\
\text { (5-10 tahun kedepan) } \\
2030\end{array}$ \\
\hline $\begin{array}{l}\text { - Mulai membentuk EA } \\
\text { pada setiap unit kerja. } \\
\text { - Pemeliharaan situs kuliah. } \\
\text { - Pemeliharaan proses } \\
\text { registrasi online. } \\
\text { - Pemeliharaan website } \\
\text { Universitas. } \\
\text { - Maintenance server. } \\
\text { - Pembaruan perangkat } \\
\text { keras pada lab dan unit } \\
\text { kerja } \\
\text { - Pengadaan Accsess Point }\end{array}$ & $\begin{array}{ll}\text { - } & \text { Pembuatan sistem E- } \\
& \text { Recruitment atau SIM PMB } \\
\text { - } & \text { Pembuatan SIM Stakeholder } \\
\text { - } & \text { Pembuatan SIM Sinta (Sistem } \\
& \text { informasi tugas akhir) } \\
\text { - } & \text { Pembuatan SIM Carrier } \\
\text { - } & \text { Pembuatan SIM Perpustakaan } \\
\text { - } & \text { Pembuatan SIM Alumni } \\
\text { - } & \text { Mulai menggunakan SMS } \\
& \text { Gateway } \\
\text { - } & \text { Pembuatan SIM Akademik }\end{array}$ & $\begin{array}{l}\text { - Pengadaan ruang server. } \\
\text { - Membangun Teknologi } \\
\text { VLAN. } \\
\text { - Menggunakan kemanan } \\
\text { jaringan yang baik. } \\
\text { - Rekrutmen SDM bidang } \\
\text { IT. } \\
\text { - Semua unit menggunakan } \\
\text { SI terintegrasi. }\end{array}$ \\
\hline
\end{tabular}

\section{KESIMPULAN}

Keselarasan strategi bisnis dan strategi IT menciptakan sebuah korporat yang berdaya saing tinggi, implementasi EA menjadi solusi pemenuhan kebutuhan dalam bidang IT dan Bisnis agar menciptakan kerangka kerja yang efisien dan efektif. Dalam penelitian ini mengkaji 5 fase dalam TOGAF ADM yang selanjutnya menghasilkan blueprint arsitektur bisnis, arsitektur data, arsitektur aplikasi dan arsitektur teknologi untuk bisa diterapkan secara khusus untuk mendukung implementasi EAP pada Universitas Pattimura.

\section{SARAN}

Saran untuk penelitian selanjutnya yaitu melanjutkan fase yang diterapkan oleh TOGAF ADM meliputi Opportunities and Solutions, Migration Planning, Implementation Governance, Architecture Change Management dan Requirements Management untuk penyempurnaan dalam penerapan EAP Universitas Pattimura.

\section{DAFTAR PUSTAKA}

[1] N. A. A. Bakar, S. Harihodin, and N. Kama, "Assessment of Enterprise Architecture Implementation Capability and Priority in Public Sector Agency,” Procedia Comput. Sci., vol. 100, pp. 198-206, 2016.

[2] R. Ansyori, N. Qodarsih, and B. Soewito, "A Systematic Literature Review: Critical Success Factors to Implement Enterprise Architecture," Procedia Comput. Sci., vol. 135, pp. 43-51, 2018.

Pariama, et., al (Enterprise Arsitektur Planning (EAP) untuk Universitas Pattimura Menggunakan TOGAF ADM) 
[3] L. A. Kappelman and J. A. Zachman, "The Enterprise and Its Architecture: Ontology \& Challenges,” J. Comput. Inf. Syst., vol. 53, no. 4, pp. 87-95, 2013.

[4] E. I. Niemi and S. Pekkola, "Enterprise Architecture Benefit Realization: Review of The Models and A Case Study of A Public Organization," Data Base Adv. Inf. Syst., Vol. 47, No. 3, pp. 55-80, 2016.

[5] R. Foorthuis, M. van Steenbergen, S. Brinkkemper, and W. A. G. Bruls, "A Theory Building Study of Enterprise Architecture Practices and Benefits,” Inf. Syst. Front., Vol. 18, No. 3, pp. 541-564, 2016.

[6] H. T. Wagner and J. Meshtaf, "Individual IT roles in business - IT alignment and IT governance," Proc. Annu. Hawaii Int. Conf. Syst. Sci., vol. 2016-March, pp. 4920-4929, 2016.

[7] S. Kaisler and F. Armour, "15 Years of Enterprise Architecting at HICSS: Revisiting The Critical Problems,” Proc. 50th Hawaii Int. Conf. Syst. Sci., no. January, 2017.

[8] H. Tsuchiya, S. Yamamoto, Y. Murakami, T. Yanagisawa, N. Kobayashi, and J. Wan, "Two-Stage Third-Party Review Proposal Using The Enterprise Architecture In Software Development," Procedia Comput. Sci., Vol. 126, pp. 1187-1196, 2018.

[9] M. Zhang, H. Chen, and A. Luo, "A Systematic Review of Business-IT Alignment Research with Enterprise Architecture," IEEE Access, vol. 6, no. March, pp. 18933-18944, 2018.

[10] G. P. Negara, A. Wahju, and R. Emanuel, "Enterprise Architecture Design Strategies for UGK Using TOGAF ADM,” No. October, 2019.

[11] A. K. Jallow, P. Demian, C. J. Anumba, and A. N. Baldwin, "An Enterprise Architecture Framework for Electronic Requirements Information Management," Int. J. Inf. Manage., vol. 37, no. 5, pp. 455-472, 2017.

[12] N. Mayer, J. Aubert, E. Grandry, C. Feltus, E. Goettelmann, and R. Wieringa, “An Integrated Conceptual Model for Information System Security Risk Management Supported by Enterprise Architecture Management," Softw. Syst. Model., Vol. 18, No. 3, pp. 2285-2312, 2019.

[13] J. S. Suroso and M. A. Fakhrozi, "Assessment of Information System Risk Management with Octave Allegro at Education Institution," Procedia Comput. Sci., vol. 135, pp. 202-213, 2018.

[14] V. Goepp and M. Petit, "Insight from A Comparison of TOGAF ADM and SAM Alignment Processes,” IFAC-PapersOnLine, vol. 50, no. 1, pp. 11707-11712, 2017.

[15] R. Pergl, R. Lock, E. Babkin, and M. Molhanec, “Organizational Modeling,” pp. 159-173, 2017.

[16] J. P. Meneses-Ortegon and R. A. Gonzalez, "Knowledge Management Framework for Early Phases in TOGAF-Based Enterprise Architecture," IC3K 2016 - Proc. 8th Int. Jt. Conf. Knowl. Discov. Knowl. Eng. Knowl. Manag., Vol. 3, No. Ic3k, pp. 31-40, 2016. 